\title{
When dismissal becomes a business transaction: Analysis of the processes and consequences of haken-giri under the global recession*
}

SHINJI KOJIMA

\begin{abstract}
This article analyzes the particular circumstances of temporary dispatched workers (haken rodosha) and a feature of their job insecurity as one facet of the growing inequality in contemporary Japanese society, focusing on the relative ease with which these workers are dismissed both legally and in practice. By contrasting with other more familiar forms of insecure labor in Japan, the paper examines the triangular relationship involving the three parties that characterize dispatched labor: the user, the employer, and the employee. The Worker Dispatching Act, which was enacted and then deregulated, enabled Japanese corporations to use dispatched workers while securing the capacity to remove them from their workplaces as a business transaction and not within the bounds of an employer-employee relationship. Using the theoretical framework of risk, the paper analyzes the emergence and spread of the triangular labor relationship as risk being shifted from the corporate level to the individual dispatched workers. It examines the consequences of the shift of risk by introducing cases of dismissal from fieldwork conducted during the global recession over the winter of 2009.
\end{abstract}

Keywords: risk; inequality; temporary employment; non-standard work; flexibility; deregulation.

\section{Introduction}

On New Year's Eve, 2008, Hibiya Park in central Tokyo suddenly turned into an emergency refugee camp providing shelter and food to over 500 people. This Haken Mura or Temp Village was not a response to a natural disaster, but a consequence of the global fiscal crisis that had suddenly made hundreds of thousands of able-bodied Japanese men both jobless and homeless. The impromptu refugee camp was gray and cold, which made all those present truly appreciate the warmth of the 
sun during the day. Today, dents in the asphalt paving in Hibiya Park from the heavy industrial cooking equipment that was used to feed the villagers spark memories when veterans of the Haken Mura crisis re-visit the park (THJI 2009: 145).

Since the labor union officials and labor lawyers, who were the main organizers of the Village, had no idea how to cook for and feed large numbers of people outdoors, they acquired the knowledge from civil society groups, who had expertise in cooking and feeding the day laborers and the homeless, to prepare for the cook-out (Utsunomiya and Yuasa 2009: 54-55). Donated bags of rice, boxes of carrots and radish, soba, and mochi were stacked in a corner of the village area. The villagers waited in long lines to receive a steaming bowl of soup and rice balls that quickly turned cold in the freezing Tokyo winter. Volunteers, who were distinguished from the villagers by bandanas tied around their arms, lent a hand making rice balls, sorting out the heaps of donated used clothes and blankets, and packaging dry foods to hand to the villagers. The villagers were not only the recipients of these social services; many lent a hand to help the village run smoothly throughout the six days of its existence.

Labor union members and labor lawyers took turns counseling the villagers to ascertain the specific circumstances of each individual in order to determine the kinds of assistance they needed. NPOs with expertise in assisting the homeless gave an outdoor lecture to the villagers about the process of applying for welfare assistance. Rented dome tents were scattered around a section of the park until the number of villagers overflowed, leading to the opening of the auditorium of the Ministry of Health, Labour, and Welfare, located across the street.

The deliberate placement of the Haken Mura right across the street from the Ministry of Health, Labor and Welfare building brought public and political attention to a new category of insecure labor that is the polar opposite of the vaunted Japanese permanent employment system; that is, temporary workers dispatched by employment agencies to factories on short-term contracts that also include arrangements for dormitory housing near the work site. When companies cut back in the wake of the fiscal crisis, the dispatched workers lost not only their employment, but also their housing. To compound their problems, without a regular address these unemployed workers faced difficulty in applying for welfare assistance. ${ }^{1}$ The lawyers, labor unions, and civil society volunteers who created the Haken Mura solved this problem creatively by faxing their welfare applications collectively to the Chiyoda Ward office, using Hibiya Park as their current domicile. Faced with close media attention and civil society support for the displaced workers, the Minis- 
try was shamed into accepting the arrangement as an emergency measure.

Although there are several other more traditional forms of insecure labor in Japan, the phenomenon of short-term workers dispatched to work in large factories through contracts with temporary employment agencies is a legal arrangement that emerged in 2004 as a result of changes in the Worker Dispatching Act. The effect of the neoliberal deregulation of the law that enabled the use of dispatched workers was to shift the risk constantly faced by corporations in the global economy on to the backs of individual dispatched workers. Theorists on the concept of risk (Giddens 2003 [1999]; Beck 2004 [1992]) have claimed that a new form of modernity is characterized by man-made risks that are widespread, affecting populations on a global scale, to which individuals with unequally distributed resources respond, creating uneven consequences of risk aversion. This study is about the unequal distribution of risk on the dispatched workers as a consequence of risk aversion by Japanese manufacturing industry. It demonstrates the process and consequence of risk being shifted from the corporate level to the individual through neoliberal labor law reforms. While corporations are vulnerable to global economic forces, they have been able to minimize such risk systematically by shifting risk on to the dispatched workers. Like many social phenomena, issues inherent in this labor arrangement were obscured until a crisis caused the system to collapse, revealing its fundamental inequities as workers were suddenly left stranded without work, housing, or any source of income.

In this paper I analyze one facet of the growing inequality in contemporary Japanese society by examining the particular circumstances of temporary dispatched factory laborers and a particular feature of their job insecurity: namely, the relative ease with which these workers can be dismissed - both legally and in practice. I begin by contrasting dispatched labor with other more familiar forms of insecure labor in Japan and identifying its unique characteristic: a triangular relationship involving the three parties of user, employer, and employee. I then narrate the historical process of how the dispatched labor system came into being, and the sequence of deregulation events that led to the rapid growth of dispatched workers in factories at a time when companies sought greater labor flexibility to deal with economic uncertainty, and when a large pool of able-bodied workers were for a variety of reasons willing to take temporary dispatch jobs. Using data from my fieldwork, I show how the temporary dispatch system was structured, and what happened when it suddenly collapsed. 


\section{Research method}

The study uses data collected during my dissertation fieldwork from April 2008 to September 2009 in Tokyo and the suburban Kanto region. I began the research by working several stints of dispatched day laboring and a month of work in an auto-parts factory in Kanagawa as a dispatched worker, gathering notes on the everyday life of dispatch work in the factories and conducting interviews with fellow workers. I then began to follow what was happening to the workers who had been thrown out of work by participating in protest events concerning dispatched work and volunteering for several days at the Temp Village over the New Year period. I then joined the general Shutoken Seinen Union as a researcher, and conducted participant observation of union activities. From January to September 2009, I attended collective bargaining negotiating sessions as a union member, and participated in demonstrations and rallies that the union organized, as well as joint actions organized by a coalition of general unions and civil society organizations tackling the issue. Interviews were conducted with union members, former temp agency employees, non-unionized dispatched workers, journalists, and union representatives of other general unions and national-level corporate unions.

\section{Historical precedents of using external labor force}

What is known as the Japanese just-in-time system, a contemporary mode of manufacturing in which parts are delivered in small amounts just when they are needed, has a historical precedent when taking into consideration the purposeful recruitment and use of a peripheral labor force in order to minimize labor costs. The principle at work behind this form of labor is the logic of recruiting labor only in the necessary amount and only when needed. This principle stands in stark contrast to the famed Japanese system of long-term labor security offered to regular employees, including managers and unionized white-collar and blue-collar workers, who are generally hired directly after school graduation and employed until retirement. These are two sides of the same coin: in order to protect the benefits provided to their regular, permanent work force, companies hire only the necessary minimum of regular workers and use the external labor force flexibly to meet fluctuations in labor needs.

\subsection{Day labor and the middleman (tehaishi)}

Insecure labor is not a new phenomenon in Japan. Day laborer communities, such as Tokyo's Sanya, Yokohama's Kotobuki, and Osaka's Kamagasaki, are well established and have been the subject of considerable 
academic research (Fowler 1996; Gill 2005 [2000]; Gill 2001; SSG 1999; Tsukada 2005). Major Japanese companies have a vertical relationship with smaller subcontractors, which are independently owned but bound together in long-term relationships (keiretsu). Since the 1950s, major companies have used the keiretsu as a buffer in economically difficult times (Imai 2004: 4). At the very bottom of this hierarchical order are day laborers, who are recruited by small companies at the bottom of the keiretsu. Established communities of day laborers provide affordable housing in flophouses (doya) that can be rented on a daily basis, surrounded by cheap eateries, shower facilities, and pachinko parlors. Residing in these doya, day laborers either find work at an open-air informal labor market (yoseba) through a job broker (tehaishi) or at the public labor exchange office located in the area. At these locations and at other sites around the urban core, workers gather early in the morning to meet the labor brokers at the open market or to find work from public job referrals offering daily, weekly, or even longer jobs to meet the shortterm labor demands of smaller companies, predominantly in construction.

My short visit to Nishi Toyama Park, one of the smaller yoseba in Tokyo, demonstrated that the informal labor market for day laborers still exists, with a middleman selecting workers and sending them to work for small construction companies. Numerous elderly men gathered in the park, looking for short-term work for a day, week, or month. Mini buses were parked around the edges of the park waiting to transport workers to suburban locations where they could live temporarily in special workers' housing (hamba) while working for a month or so. A tehaishi wearing dark glasses walked up to me, looked at me from head to toe, and said, "You a rookie?" "Yes, it's my first time here," I replied. Even though it was apparent that I had come empty handed, without the three sacred tools of day laboring, namely safety boots, safety belt, and work wear, I was the only young, able-bodied person there. He nodded at my response and said, "You want to go?"

The existence of such day laborers and labor markets with a middleman dates back to the pre-modern era, and continues to this day. These day laborers do not work in factories but mostly at construction sites. The physical space of yoseba and doya set geographic limitations for recruitment of those potential short-term laborers, but this situation was radically transformed by the introduction of worker dispatching as a legal business. Such flexible recruitment of precarious labor on an employ-as-needed basis was applied nationwide across industries via the introduction of the Worker Dispatching Act in 1986. 


\subsection{Ukeoi and the informal practice of triangular labor relations in manufacturing}

The use of short-term contract workers provided by a labor supplier also has a history in the manufacturing industry. Using external labor provided by a labor supplier was made illegal in 1948 under the Employment Security Act, which turned the workers that used to be informally hired by labor bosses into directly hired, temporary workers (kisetsu kī or rinji $k \bar{o})$. At the same time, a system of triangular labor relations called ukeoi was defined and regulated in concrete legal terms. Besides the directly hired temporary workers, who were mainly farmers with free time during the winter season, there existed a host of subcontracted workers who were direct employees of a company that engaged in work which had been subcontracted out within the physical space of a factory. The main company that owns the factory outsources an entire work process, hiring an independent subcontractor that takes responsibility for producing an end product. When this subcontracting relationship takes place within the subcontracting factory's premises, such as taking responsibility for running an entire assembly line, this form of work was called subcontracting within the premises (könai ukeoi).

The Employment Security Act set a strict standard regarding ukeoi work to distinguish it from labor dispatching. One requirement was that workers could only take work orders and directions from employees of the subcontracting company, and not directly from employees of the main company, which may be regarded as the end user of the subcontracting company's labor force. While the Employment Security Act initially set strict standards for the ukeoi system, the provisions of the law were later eased and thus a gray area was created in which an illegal form of $u k e o i$ was practiced, a form that in contemporary terms would be deemed as labor dispatching (Okamura 2009: 122-123). In some cases, the user company's employees gave direct work instructions and orders to the employees of the subcontracting company, essentially turning the relationship into one of third party employee without a direct employment relationship (Imai 2004: 6). The use of this type of external labor force to manage fluctuations in production - a kind of safety valve - was practiced informally on the shop floor.

\section{Expanding the logic of just-in-time labor by legalizing worker dispatching}

Scholars are in agreement that the Worker Dispatching Act was enacted partly in response to the spread of an illegal use of the external labor force (Imai 2004; Takanashi 1987; Wakita 2008). As noted above, in 
manufacturing plants the illegal use of workers that were not the company's own employees was prevalent using the ukeoi system as cover. In offices, the use of primarily women office workers supplied by human resource providers grew unchecked after the U.S.-based multinational corporation Manpower opened an office in Japan in 1966 (NJSK 1996: 9). The government deemed the underground growth of this illegal use of labor as reflecting the needs of both the users of labor and the workers, yet viewed it as a situation requiring regulation. The government legalized the de facto triangular relationship in order to control the spread of the illegal use of workers.

After a series of committee hearings inviting representatives from the business community and labor, in addition to academics, the Act was passed in $1986 .{ }^{2}$ It legalized two types of worker dispatching: full employment type (jōyo koyō-gata) and registered type (tōroku-gata). The full employment type legalized what had been practiced underground under the disguise of the legal ukeoi system, in which a full-time employee of a subcontractor was sent to work at a user company under the orders and directions of the user company. The registered type of worker dispatching introduced the logic of just-in-time usage of an external labor force, which has existed historically in Japan and can still be seen today in day laboring with a middleman. While the full employment type theoretically employs the dispatched worker full time, meaning that as an employee of the subcontracting company the worker receives pay even when not working for and at the user company, the registered type follows a different logic. In the registered type of dispatching, the temp agency maintains a pool of registered workers, from which it employs dispatched workers and signs an employment contract only upon the availability of work.

The Worker Dispatch Act at its inception was relatively restrictive. The Act legalized 13 occupations, and imposed a limit on the length of time that industries could use the dispatched workers. A nine-month limit was set for 12 occupations, and a one-year limit for the one remaining occupation. In effect, the new Worker Dispatch Act upheld the preceding norm of Japanese employment practice, the principle of a dyadic, direct employment relationship between the user/employer and employee, and merely legalized these specific occupational categories as exceptions. But since the inception of the Act in 1986, a series of deregulations has expanded the legally excepted occupational categories and raised the time limit. In 1996, the list of legal occupations for dispatch was expanded to 26. After the bubble economy burst, the Act was again deregulated in 1999, this time as a radical break from the past law. The revision reversed the process by lifting the general ban on dispatched workers except for specified occupational categories. The law now listed 
four specific occupations in which it was illegal to use dispatched workers, including work in factories, and legalized the rest. The final deregulation was implemented in 2004, which allowed dispatched workers to be sent to factories. The 2004 deregulation initially imposed a one-year limit on the use of dispatched workers in factories, which was later extended to three years.

\section{The terms and nature of dispatched factory work}

Working as a registered-type dispatched worker in the factories has its own unique and manufactured appeal. Finding work is akin to satisfying one's hunger at a fast food joint: it is immediate, available, and appealing. It is unhealthy yet permissible as a temporary measure. The low entry hurdle established for dispatched work in the factories and the speed of securing work makes dispatched work accessible for those who have no marketable skills yet urgently seek employment. Dispatched work is advertised in free papers stacked at train stations and convenience stores, listing appealing wages that are often set slightly higher than local part-time jobs, luring near-sighted job seekers who are more anxious about making a living this month than thinking about next year. Temp agencies are omnipresent nation-wide, and have established a network of offices that effectively mobilizes potential workers from suburban and rural areas where employment is scarce.

Dormitory rooms are readily available, making possible the swift movement of laborers from their current residence to the place of work. Those potential workers without the resources to rent an apartment find dispatched work appealing partly due to this availability of a dorm. In my case, while the temp agent briefly skimmed my resume, I was asked to fill out a form to be registered on their database as a job seeker. I took several tests, including gripping the hand dynamometer, a simple math test, and a dexterity performance test (placing a washer onto a screw and repeating it). The latter two tests were timed. It took only one week from my first visit to the temp agency office to finding myself sitting in a dormitory provided by the temp agency.

As a result of two-decade's worth deregulation of the Worker Dispatch Act, lifting bans on categories and expanding the time limit, the number of dispatched workers working under the just-in-time labor supply principle has increased (see Figure 1). In their study, Kalleberg and colleagues defined "bad jobs" (Kalleberg, Reskin and Hudson 2000: 260) as being characterized by low earnings, lack of health insurance, and lack of pension benefits. They found that in the United States non-standard work arrangements, such as part-time employment, day labor, oncall work, and temporary-help agency and contract work, are all more 


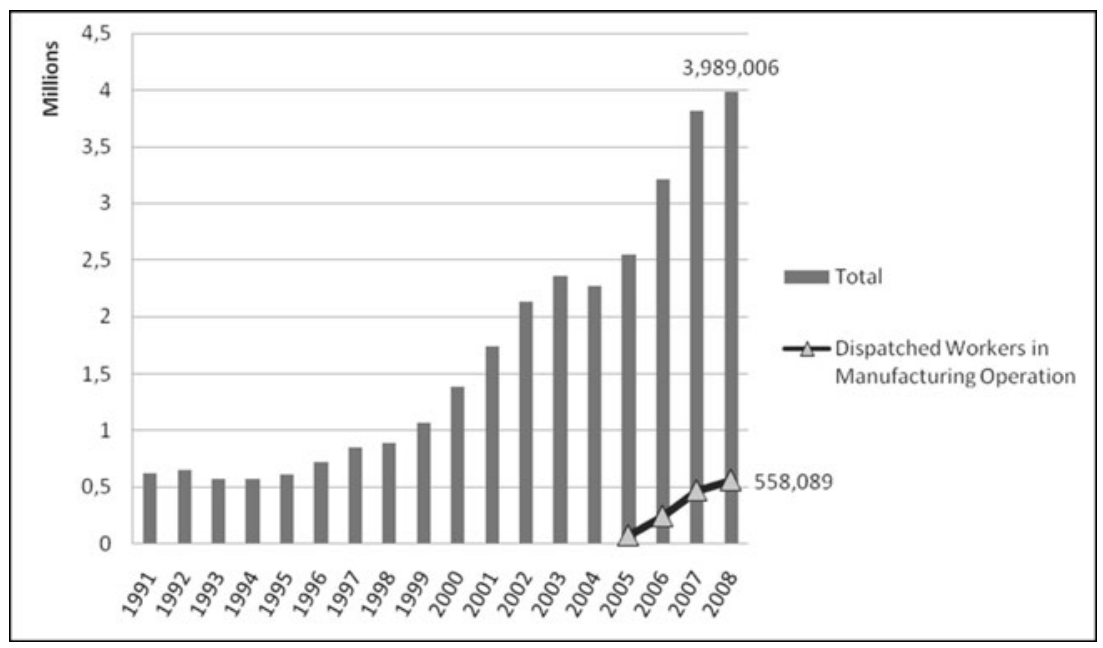

Figure 1. Number of Dispatched Workers.

Source: Ministry of Health, Labor and Welfare (MHLW 2009c).

likely to be associated with bad job characteristics than standard work arrangements; and they also argued that non-standard work arrangements, especially temp agency employees, day laborers, and part-timers, are likely to lack employment security, fringe benefits, and unionized structures, and thus face a package deal of bad job characteristics (Kalleberg, Reskin and Hudson 2000: 261, 273). Some parallels can be observed among Japanese registered-type dispatched workers.

A 2008 Japanese government survey revealed that while 91 percent of dispatched workers depend on their own income for their living, more than half of these workers are paid less than 1,250 yen per hour (MHLW 2008a). And when it comes to registered-type dispatched workers on the assembly line, the average hourly pay is even lower at 1,100 yen (MHLW 2005). Dispatched workers on the assembly line earn approximately 63 percent to 66 percent of what regular workers earn working the same job for the same hours with similar on-the-job work experience and in a comparable age category. ${ }^{3}$ One of the critical differences between dispatched workers and the regular workers' annual income is the lack of bonus benefits for the dispatched workers. One of the main complaints of the dispatched workers is that their wages are low compared to regular workers working on the same task. ${ }^{4}$ Another critical difference is the lack of evaluation criteria applied to dispatched workers, which in the case of regular workers results in regular wage increases over time. In Japan, the seniority-based wage system means that the age of an em- 
ployee and the length of service for the company are the two main factors reflected in gradually increasing wages. When it comes to dispatched workers, the hourly wage remains the same regardless of age and length of service. ${ }^{5}$

Regarding the terms of contract, registered-type dispatched workers are usually on short-term employment contracts, with 50 percent of them working under a contract of less than six months. Yet, similarly 50 percent of them have been working on the job longer than one year, of which 14.5 percent have been working the same job for more than three years. This suggests that while there is work that needs to be done, and the demand for workers to perform these tasks is not necessarily considered to be of a temporary nature, the user corporations have been using the dispatched workers over an extended period of time by having the temp agency repeatedly renew the short-term employment contract with its employees. This pattern is strikingly similar to the pattern observed in the worker-dispatching contracts signed between the user corporations and the temporary help agencies and the overall length of current contracts between the two (see Figures 2 and 3). While the business contract of providing and being provided with contract-dispatched workers

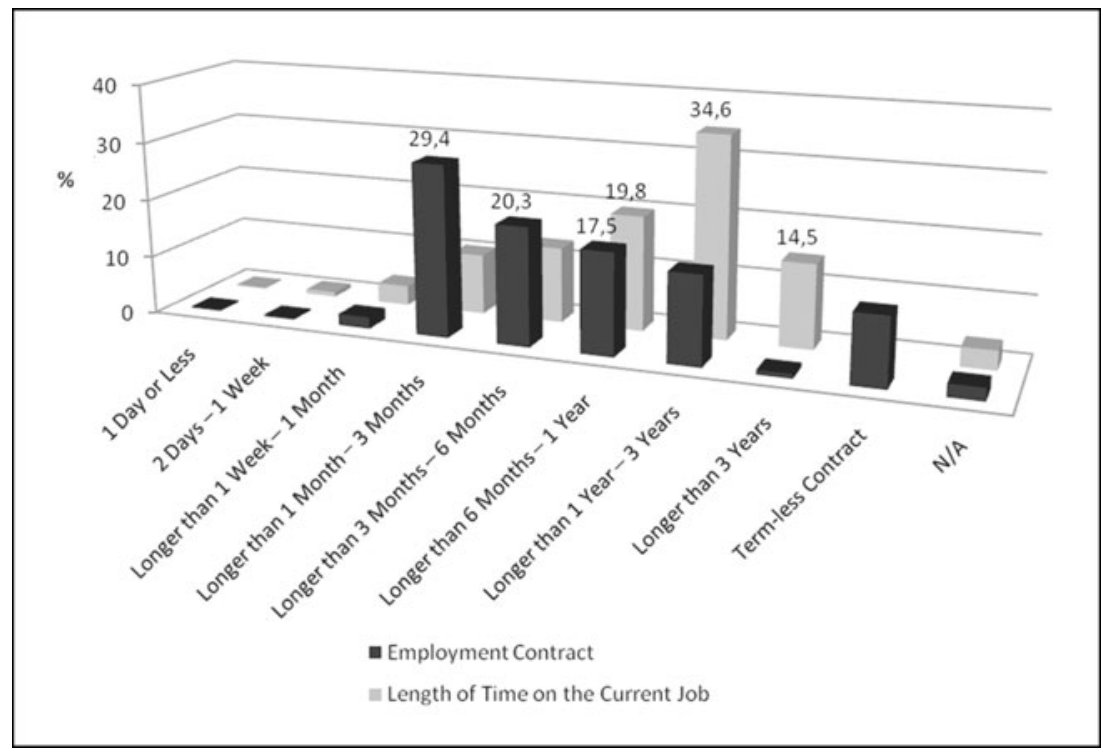

Figure 2. Comparison of contract terms and length at work: Registered-type dispatch Workers.

Source: Ministry of Health, Labor and Welfare (MHLW 2009b). 




Figure 3. Comparison between term of dispatching contract and length of present contract.

Source: Ministry of Health, Labor and Welfare (MHLW 2009b).

is maintained for only a short period, the short-term contract is renewed repeatedly, allowing the user corporation to avoid risk arising from uncertainties in the global market by signing short-term contracts for external labor through the temp agency, and renewing it only upon necessity. The user corporations can terminate the contract with minimal loss, resulting in a pattern of short-term contract and renewal with the temp agency, which then gets applied to the dispatched workers' employment contract, leading to an insecure working arrangement for the dispatched workers.

Dispatch work in factories can be considered a dead-end job. Mobility chances for dispatched workers to become regular workers are scarce. To begin with, the majority of dispatched workers do not choose to become a dispatched worker out of preference for this kind of employment arrangement. The majority would prefer regular employment (MHLW 2008a). ${ }^{6}$ This is because regular employees have relatively strong job security. Yet the question remains whether a route is open for workers to enter a workplace as a dispatched worker in hopes of building work experience, gaining competence through on-the-job training, and being re-hired as a regular employee of that workplace. Article 40-4 
of the Worker Dispatching Act specifies that when the user company reaches the time limit for using a dispatched worker, it must offer a directly hired position to the worker concerned if the company wishes to continue to use that worker and if the concerned dispatched worker wishes to become a direct employee of the company. Article 40-3 and 40-5 state that if the user company wants to hire directly a worker to resume the same work that is being done by a dispatched worker who has been servicing the corporation for over a specified period as outlined in the Act, the user corporation must prioritize hiring the dispatched worker already on the same work. While these statutes look good on paper, a government survey shows the reality to be less so. According to the 2008 MHLW survey, 86.5 percent of corporations do not even have a route established for dispatched workers to be re-hired by the corporation directly. A further 3.4 percent of corporations have an established route, yet have never promoted a dispatched worker to direct employee. That leaves just 9.1 percent of corporations that have ever re-hired a dispatched worker as a direct employee (MHLW 2009b). This means not only that the dispatched workers' hopes for using the dispatched work system as a channel to direct hire are unlikely to materialize, but also that dispatched workers have remained dispatched workers for reasons that require further inquiry. ${ }^{7}$

Some researchers have claimed that the dispatched work system represents a diversity of work values and not necessarily that of inequality (see, e.g., Sato 24 August 2006; Sato 2008). The system has enabled workers to attain the liberty of choosing work styles, workplaces, changing workplaces, and experiencing multiple workplaces, with the possibility of building a career out of the experiences and skills gained. But as Kalleberg, Reskin, and Hudson (2000) have argued, the liberty and flexibility that are claimed to have benefited the workers come at a high price.

\section{The structure and culture of insecurity}

From the user corporations' standpoint, the Worker Dispatching Act is valuable because the law enables the users to use an external labor force flexibly as a way to respond to the vicissitude of the market. ${ }^{8}$ The nature of job insecurity for the worker arises out of the structure of the Act. Since it was enacted for the user corporations to manage labor according to market shifts, naturally it makes removing dispatched workers relatively easy and swift, compared to removing regular workers sharing the same workplace. Employment of dispatched workers is frequently terminated even before their short contracts are up as a knee-jerk response to user corporations terminating their contract with the temp 
agency, an event known as cutting the dispatch or haken-giri. To understand what happens requires closer examination of the triangular contractual relationship underlying dispatched work.

The worker-dispatching contract is signed between the user company (the de facto employer of the worker) and the temp agency (the de jure employer of the worker). The termination by the user corporation of the contract prior to its expiration is a civil matter in which the state does not intervene. While managing the early termination of the contract between the user company and the temp agency is left to these two private parties, the Ministry of Labor, Health, and Welfare has issued a ministerial notification that outlines the requirement imposed upon the user corporation to give the temp agency thirty days advance notice of its decision to dissolve the contract (MHLW 1999). In cases where the user corporation does not give advance notice, it must pay the temp agency an amount greater than thirty days of wages of the affected dispatched worker. Furthermore, the user corporation is to make efforts to secure alternative opportunities for work by offering the dispatched worker affected by the termination of contract a position at an affiliated company. While in theory the user corporation must obtain the mutual agreement of the temp agency to dissolve the contract, in practice the power imbalance between the corporation and the agency is such that the corporation has the capacity to terminate the contract unilaterally at any time as long as the corporation is prepared to compensate the temp agency with a month's worth of wages for every dispatched worker who will end up losing his/her place of work.

When the contract is broken by the user corporation, however, the temp agency is more legally bound when dealing with its employed dispatched workers. Then labor laws come into play because the relationship between the temp agency and the dispatched workers is an employer-employee relationship. Article 17 of the Labor Contract Act prohibits the dismissal of workers under fixed-term contracts unless there are "unavoidable circumstances" (yamu o enai jiy $\bar{u}$ ). Since the specific term length is based on an agreement which binds the employee and the employer in a contract, the term must be met and kept. The employer has a narrower window for proving "unavoidable circumstances" compared to dismissing a regular worker under an unlimited contract term, which is difficult to do under Article 16 of the Labor Contract Act and in consideration of the judicial rulings that have accumulated on this issue. Thus, while the legality of dismissal must be judged case by case, the bar is set high for dismissing a dispatched worker on a fixed-term contract prior to its expiry. In cases where the temp agency must do so, such as in the hypothetical case of the agency going bankrupt, the ministerial notification states that the temp agency 
must attempt to secure an alternative place of work for the dispatched workers in cooperation with the user corporation. The temp agency must also abide by the Labor Standards Act, according to which the employer must give thirty days advance notice to the employee concerned, or else compensate the worker to be dismissed with a full-day's average pay for every day short of the thirty-day advance notice. Thus, in cases where the user corporation terminates a contract prior to expiry, that in itself should not automatically lead the temp agency to dismiss the dispatched workers. The agency must maintain the employment contract with the dispatched workers at least until it expires, despite the termination of contract between the user corporation and the temp agency. If there is no other work available the agency must still compensate the worker with at least 60 percent of the average daily wage according to the Labor Standards Act. Thus, in principle, and unless it is unavoidable, the temp agency cannot break its employment contract and must compensate for the lack of work while the contract is in effect.

Yet, despite the high legal bar set for terminating the employment contract before expiry, due to the fact that the registered-type dispatch workers' contracts are predominantly fixed term (usually three to six months), these workers can immediately become jobless as soon as the contract expires. Although it is difficult to generalize, when it comes to the non-renewal of employment contracts for registered-type dispatch workers working on the assembly line - given the underlying assumption of dispatched work being of a temporary nature with a maximum three-year limit - it is relatively easy during economically difficult times for a temp agency to release the worker by simply not renewing the contract, compared to releasing a regular worker on an indefinite contract - as some temp agencies did when Japan experienced the impact of the global recession in 2008 .

In addition to these legal structures that enable companies to respond swiftly to market shifts by removing the dispatched workers, the familylike relationship between employer and employee that typically characterizes Japanese workplaces is not formed with either the de facto employer or the de jure employer. During the training program in a factory I entered as a dispatched worker, the trainer told the group of newly dispatched workers, of which I was a part, that "Today, from the moment you all wear our uniform, you are a $[\mathrm{X}]$ man." The $\mathrm{X}$ can be replaced with any manufacturing company's name, such as Nissan or Canon. Yet, in an interview, a plant manager who uses registered-type dispatched workers told me candidly, "They [i.e., the dispatched workers] are not in the same boat as us." These ambivalent attitudes toward dispatched workers complicate the situation of dispatched work in the factory culturally, while the principle of the registered-type dis- 
patching system - that is, the just-in-time use of the external labor force - is applied without remorse at economically difficult times, and hence the swift response to global recession is to treat these workers not as Nissan men or Canon men, but as "there-to-be-released" workers. On the other hand, the temp agencies dealing with registered-type dispatching have a hard time recognizing themselves as legally-bound employers of dispatched workers, just as the tehaishi have a hard time imagining themselves as employers of day laborers. While the temp agencies are employers on paper, they do not use the dispatched workers to perform productive services for the temp agency, as in dispatched workers performing services for the user company. There is no everyday face-to-face interaction between the temp agent and the dispatched workers comparable to the everyday interaction the agents have among themselves or the dispatched workers having daily interactions with the regular employees of the user corporation. There is no strong emotional bond between the agents and the dispatched workers so they do not see each other as family members sharing the same fate; rather these workers are considered a mobile set of work units to be dispatched when there is work and severed when there is none. It is these cultural understandings held by the de jure employers that led, in part, to the hasty release of dispatched workers during the global recession.

These legal structures enable the flexible use of dispatched workers in the factories. When the user corporations are freed from the legal status of "employers of workers" by the introduction of a legitimate middleman (i.e., the temp agencies), they can easily remove the dispatched workers by simply terminating the business contract with the temp agency. It is then left in the hands of the temp agencies to deal with these dispatched workers, who have not only just lost a place of work, but can also be released relatively easily by not renewing the short fixedterm contract. The following section describes three examples of how dispatched workers were released during the recession.

\section{Insecurity in practice: Cases of haken-giri}

The first example is Kida ${ }^{9}$, whom I met at the Haken Mura. I chatted informally with him while we were smoking at the designated spot located next to the main tent. Kida, a male in his late twenties, had been working for six years as a dispatched worker. During that time, as he hopped around three manufacturing companies, his four years of work at an auto-parts factory in Nagoya were most memorable. During his four years of service there, his mother, the only parent he maintained contact with, was diagnosed with a fatal condition and was immediately hospitalized. He asked his temp agent if he could take a short leave to 
visit his mother. The agent responded, as Kida put it to me, "Then could you quit?" Noting my stunned expression, he continued: "Yeah ... Exactly ... There are many others like me for a quick replacement."

With a sense of resignation, he left the job to visit his mother, who soon passed away. Kida was ready to return to work after three days. He quickly found another dispatch job, this time from a different temp agency that offered work at an electronics factory in Mie Prefecture. He worked there for two months, only to find himself released from work on December 20, 2008. Since it was his first term on a two-month contract, the law allowed the temp agent, with no advance notice, to not renew his contract. The agent told him that his work at the factory was over and to vacate the dormitory as soon as possible. He gathered his belongings and left the dorm. After spending several nights at an Internet café in Shinjuku, he found information on the Internet that led him to the Haken Mura.

The second example is Higa, a 50-year-old single male. Although we were dispatched from different temp agencies, we worked for the same auto-parts factory in Kanagawa Prefecture. I got to know him after entering work on the same day and going through the two-hour safety lecture in the morning of our first day at work. After interviewing him before I left the job, I continued to keep in touch with him by phone and the occasional eat-out. He has been working as a dispatched worker for over ten years, which reveals that dispatched work was practiced in the factories well before legalization in 2004. He experienced haken-giri twice, once in October 2008 and then again in March 2009. On the first occasion, he received a phone call from his agent on the day he was dismissed. It was October 31 when the agent told him on the phone, "We received a notification from $X$ [i.e. the name of the company we used to work for] with a list of names we need to remove from the factory. I am calling everyone on the list right now." He mumbled that Higa's name was on the list and that work for him ended at the end of that month, which was the very day they were talking on the phone. The agent was quick to note that the agency would guarantee the next month's pay. "I will take requests for work again in due course. I will call you back." Although the temp agency paid a month's worth of compensation, the agent could not secure him another place of work.

Higa utilized his network of dispatch agents, one of which was able to find him work at a subcontractor for an electronics maker in Kanagawa. The temp agent came over to his dorm with a mini-van to take his belongings to the next dormitory. The reason why he was able to secure work in that economically difficult time was that he was skilled in using a soldering iron. He continued to work there until he was again dismissed at the end of March. When I called him in February on a 
Saturday, expecting him to be at home, he was at work. His workplace was busy, having him do overtime until 9 p.m. on a regular basis, sometimes even until 11 p.m. I commented that it was a tough work schedule, to which he responded, "I am lucky. I ought to be happy." One and a half months later he was dismissed. He was informed by the agent on March 10 that his work would end on the $15^{\text {th }}$. He was also asked to vacate the dormitory as soon as possible. The announcement caught Higa by surprise since his workplace was busy with daily overtime work. The temp agency later asked Higa to work until the end of March, and then dismissed him. Higa had signed his first employment contract in mid-November when he moved from his previous workplace. On the contract, the term of employment was shown as lasting until January 31, but he continued to work well after January until the end of March without a contract, which is not unusual. The only time Higa heard from the temp agent was when he was told, "Your work is over at the end of March," and to "vacate the dorm as soon as you can." No paper was handed to him regarding his contract.

As a former co-worker and possible supporter, I accompanied him to his temp agency on April 7, 2009. It was a warm sunny day that implied the arrival of spring. I dressed well to give the impression of a person of expertise in law to give myself some leverage. It was critical to talk to the temp agent in order to gather the information we needed to ascertain the legality of Higa's dismissal. As we both arrived, the agent smiled at Higa and told him in a brotherly, friendly tone, "Man, I am trying hard to find work for you, but it's tough." As we walked up the stairs to the office, he looked at me out of the corner of his eye. After a moment of silence he asked Higa, "Is he your friend?"

As we talked in the small, minimally decorated office with just two other agents present, we managed to get the temp agency to guarantee that Higa would not be asked to leave the dormitory until he secured his unemployment insurance. There was much room left to question the legality of the temp agency's dismissal, but Higa insisted that he did not wish to proceed in that direction. Rather, he preferred to end the conversation by just asking the temp agency to secure housing for him until he received unemployment insurance payments from the state.

The third and final examples are Nakamura and Hara, both of whom are in their late thirties, and both of whom I met through our shared union membership of the Shutoken Seinen Union ${ }^{10}$. Nakamura had registered with a temp agency in his hometown of Sendai, a city in Miyagi Prefecture, in April 2005 and was immediately dispatched to work for a truck manufacturer in Kanagawa Prefecture. Until his dismissal in December 2008, he worked continuously on the same assembly line, performing the same task of assembling parts around the driver's seat such 
as the brake and clutch pedals. While his work remained the same throughout his years on the job, his employment arrangement was manipulated by his employer several times. He began working as a dispatched worker employed by an agency in Sendai, but disguised as a worker dispatched from a different temp agency in Osaka - an illegal labor practice (called niju haken, or double-dispatching). Then he was instructed to become a regular employee of the Osaka temp agency, while continuing to work as a dispatched worker receiving work orders and instructions from the truck company employees - also illegal according to the Worker Dispatch Act. Finally he was instructed to register with a temp agency the Osaka agent had created to legally engage in the human resource business, beginning with a six-month fixed term contract, but later on becoming a dispatched worker on an indefinite term.

Hara had registered at a different temp agency but was dispatched to work at the same truck company in September 2005. He worked there until he was dismissed in December 2008, repeatedly renewing contracts that were two days at the shortest and six months at the longest. Both workers faced termination of their labor contracts before expiry. Hara was initially assigned an assembly task in Plant 2 until February 2006, and then was moved to work in Plant 1 from March 2006 until his dismissal, feeding parts to the assembly line while assembling electronic modules.

Right before the lunch break was about to end on November 18, Nakamura's agent came over to verbally inform him that his work at the truck company would end on December 25. Nakamura was later also asked to vacate the dorm by December 29. The conversation was a short five-minute announcement, leaving Nakamura anxious when he had to return to his position before the line started to run again for the afternoon. Hara's agent informed him on November 30 that his work at the truck company would end on the last day of December. Nakamura contacted the union after agonizing over what to do. The two workers visited the Shutoken Seinen Union office and they joined on the spot. Since then, the two, with union support, have been waging labor struggles against the truck company and the temp agencies.

\section{Conclusion}

This study has analyzed an aspect of the rise in inequality in contemporary Japanese society by focusing on the legal structure and practices of job insecurity that dispatched workers face. Risk management is a way of relating to uncertainty and attempting to control the future (Giddens 2003 [1999]: 26). In a globalized world, remote forces have an impact on geographically distant populations. While the lowering of borders has 
enabled financial entities to reach out and accumulate capital beyond national boundaries, companies have at the same time increasingly become vulnerable to tsunamis of distant seismic origin. The Worker Dispatch Act was not only a way to legalize the illegal use of labor and slim down the size of the regular work force that had potentially become a burden under the collapse of the bubble economy, it gave Japanese corporations the capacity to manage future market uncertainties by endowing them with the legal right to remove workers, not within the bounds of an employer-employee relationship but as a business transaction. The significance of the Act, and especially its 1999 and 2004 revisions, was the security it offered the corporations in responding to future uncertainties. The effect of the law was to shift the risks that a corporation would traditionally have had to deal with as an inevitable part of doing business in the global economy on to the individual dispatched workers, where it took the shape of job insecurity.

The logic behind the idea of concentrating risks into the economically and socially weak population for the sake of the larger whole is not new. The famed Toyota-system of production is based on the ideas of orderbased production and "leave no stock." Order-based hiring and leaving no labor stock, enabled by the presence of a middleman, had been practiced historically both informally and legally upon the day laborers who were geographically concentrated, predominantly working at construction sites. The use of an external work force hired by a subcontractor had been happening illegally as well under the name of ukeoi. Yet the institutionalization of the Worker Dispatch Act and its two-decade-long neoliberal deregulation have not only legitimized the above ideas and practices, but have also led to the nationwide spread of dispatched workers who face job insecurity. The structural insecurity that these workers face took on spectacular form when the risk avoidance capacity secured by the Act was practiced both legally and illegally during the global recession over the New Year period of 2009.

Shinji Kojima (skojima@hawaii.edu) is a doctoral candidate in the Department of Sociology, University of Hawai'i at Manoa. After conducting eighteen months of fieldwork in Tokyo, he is currently back in Hawai'i writing a dissertation on the work experiences, identity formation, and the emerging union activities of dispatched workers working at Japanese manufacturing plants. He specializes in the study of social stratification, social movements, and contemporary Japanese society.

\section{Notes}

* This research was funded by the Center for Japanese Studies, the Misawa Honjo International Fellowship, and the Graduate Student Organization of the Univer- 
sity of Hawai'i at Manoa. I am grateful for their financial support. I would also like to thank the anonymous reviewers for their constructive comments and the editors of this issue of Contemporary Japan for their patience. I owe my deepest gratitude to my longtime advisor Dr. Patricia G. Steinhoff. Without her academic guidance and emotional support, this paper would not have been possible.

1. By law, being without a regular address does not disqualify anyone to apply for welfare assistance, but it is one amongst a set of excuses used by the local welfare counselors in turning the applicant away. See Yuasa (2009 [2005]) and Tokairin (2008) for detailed cases.

2. For a detailed process of the emergence of the Worker Dispatching Act, see Nihon rodo nenkan volume 55 (OSK 1984).

3. A precise comparison of income between regular workers and dispatched workers is difficult, but one can attempt to calculate an estimate based on available statistics. For the purpose of comparison, in the case of dispatched workers on the assembly line, based on the average hourly wage of 1,100 yen, one can calculate an annual income imagining four work pattern scenarios: a worker (1) on a day shift throughout the year without any overtime work; (2) on a day shift with six hours of overtime work per month on average; (3) on a double-shift without any overtime work; and (4) on a double-shift with six hours of overtime per month on average.

The annual income for each hypothetical worker comes out to JPY 2,112,000, JPY 2,211,000, JPY 2,343,000, and JPY 2,442,000, which is approximately US\$23,500 to US\$27,100 as an annual income, assuming that the worker is able to secure work for the entire year consistently. The annual income of regular workers on the assembly line is available in government statistics. To make the wage comparison as reasonable as possible, I looked at the regular workers with one to four years of on-the-job experience on an automobile assembly line between the age categories of 25 to 29,30 to 34 , and 35 to 39 . They respectively earn an annual income of JPY 3,206,000, JPY 3,252,100, and JPY 3,356,800 on average (MHLW 2009a). Since information on the monthly set wage gathered in government statistics does not include additional wages provided for overtime or nightshifts, using the day shift without overtime annual income for dispatched workers would provide the closest comparison.

4. Table 28 of the "2008 Survey on the conditions of dispatched workers" (MHLW 2009b) shows that 37.7 percent of dispatched workers are not happy with their wages, while 27.7 percent are happy. Among those who were not happy, the largest single reason given ( 27 percent) was "because wages are lower compared to regular workers employed by the user company working on the same task." Table 30 of the survey demonstrates that among the 60 percent of workers who have requests to make to the temp agency, 60 percent wish for an improvement in the wage structure.

5. This point has been confirmed by interviews with two temp agencies and has been supported by every dispatched worker I have met and either talked to informally or formally in interviews. The general rule of working as a registered dispatched worker in factories is that no matter how long you stay in the job, your hourly wage does not increase. A temp agency told me in an interview that if a raise is given at all it is at best ten to twenty yen per hour. As we will later see in the cases of Hara, Nakamura, Higa, and Kida, their wages remained the same despite their long service.

6. The 2007 "Comprehensive survey on diversifying forms of employment" (MHLW 2008a) shows that the most frequently identified reason (37 percent) for choosing dispatch work was "because no company was available for a regular employment 
position." Among those who wished to continue to remain employed, 52 percent preferred not to continue as a dispatched worker, and among these, 92 percent preferred a regular employment arrangement.

7. The 26 occupations that were permitted in the 1996 revision of the Act are without time limits, which allow the user company to continuously use dispatched workers as long as the user company does not hire direct employees for the same work concerned. The rest of the occupations liberalized in the 1999 revision of the Act have a maximum time limit of 3 years. The Ministry of Health, Labor and Welfare has issued an instruction in order to prevent user companies from working around the imposed time limit by temporarily hiring the dispatched worker as a direct employee upon reaching the limit, only to re-use that worker as a dispatched worker again (MHLW 2008b).

8. According to the 2008 "Survey on the conditions of dispatched workers" (MHLW 2009b), the two most frequent reasons the user companies identified in using dispatched workers is "to enable the prompt acquiring of workers at necessary moments" and "to respond to the temporary or seasonal fluctuation in the amount of work."

9. Pseudonyms are used for every dispatched worker introduced in this paper.

10. Shutoken Seinen Union is a general union constituted of approximately $350 \mathrm{mem}-$ bers. The first labor unions to take issue with haken-giri were these general unions, synonymously called community unions. In Japanese, they bear the names komyunitc yunion and godo rodo kumiai, often attaching the word yunion as a suffix that is the direct English usage of the word union. While community unions and general unions have minor differences, such as the former having a more geographic orientation, according to Suzuki (2008), the two share the most significant characteristic vis-à-vis enterprise unions which led them to respond to the dismissal cases of dispatched workers: their keen awareness of increasing irregular work especially among the younger population who fall out of enterprise union protection; their focus on unionizing these non-unionized irregular workers; and their structural ability to incorporate these workers on an individual basis, regardless of employment arrangement and place of work.

\section{References}

Beck, Ulrich. 2004 [1992]. Risk society: Towards a new modernity. London: Sage.

Fowler, Edward. 1996. San'ya blues: Laboring life in contemporary Tokyo. Ithaca \& London: Cornell University Press.

Giddens, Anthony. 2003 [1999]. Runaway world: How globalization is reshaping our lives. New York: Routledge.

Gill, Tom. 2001. Men of uncertainty: The social organization of day laborers in contemporary Japan. New York: SUNY Press.

Gill, Tom. 2005 [2000]. Yoseba and Ninpudashi: Changing patterns of employment on the fringes of Japanese economy. In Jerry S. Eades, Tom Gill \& Harumi Befu (eds.), Globalization and social change in contemporary Japan, 123-142. Melbourne: Trans Pacific Press.

Imai, Jun. 2004. The rise of temporary employment in Japan: Legalization and expansion of a non-regular employment form. Duisburg Working Papers on East Asian Studies 62. 1-64.

Kalleberg, Arne L., Barbara F. Reskin \& Ken Hudson. 2000. Bad jobs in America: Standard and nonstandard employment relations and job quality in the United States. American Sociological Review 65. 256-278. 
MHLW (Ministry of Health, Labor and Welfare). 1999. Hakensaki ga kozubeki sochi ni kansuru shishin (Heisei 11-nen Rōdōshō kokuji dai 138-gō, saishū kaisei Heisei 21-nen Kosei Rodosho kokuji dai 245-go) [Guidelines on the measures to be taken by the user companies (1999 Ministerial notification number 138, last revised in 2009 Ministerial notification number 245)]. Tokyo: MHLW.

MHLW. 2005. Haken rodosha jittai chosa [Survey on the conditions of dispatched workers]. Tokyo: MHLW.

MHLW. 2008a. Shūgyō keitai no tayōka ni kansuru sōgō jittai chōsa [Comprehensive survey on diversifying forms of employment]. Tokyo: MHLW.

MHLW. 2008b. Iwayuru "2009-nen mondai" e no taīo ni tsuite (Shokuhatsu dai 0926001-go Heisei 20-nen 9-gatsu 26-nichi) [On the proper handling of the socalled "2009 problem" (Ministerial instruction issued by the head of the Employment Security Bureau, number 0926001, September 26, 2008)]. Tokyo: MHLW.

MHLW. 2009a. Heisei 20-nen chingin kōzō kihon tōkei chōsa [2008 Basic statistical survey of wage structure]. Tokyo: MHLW.

MHLW. 2009b. Haken rodosha jittai chosa [Survey on the conditions of dispatched workers].

MHLW. 2009c. Rōdosha haken jigyō no Heisei 20-nendo jigyo hōkoku no shäkei kekka ni tsuite [Summary of worker dispatching business annual report for the year 2008]. Tokyo: MHLW.

NJSK (Nihon Jimushori Sabisu Kyokai) (ed.). 1996. Nihon ni okeru jinzai hakengyo no ayumi: Kyokai setsuritsu 10-shanen o mukaete [History of human resource dispatching business in Japan: On the $10^{\text {th }}$ anniversary of the association's inception]. Tokyo: Shadan Hojin Nihon Jimushori Sābisu Kyōkai.

OSK (Ōhara Shakaimondai Kenkyūjō) (ed.). 1984. Nihon rōdō nenkan dai 55 shū 1985nen ban [Labor year book of Japan 1985, No. 55]. Tokyo: Rodo Junposha.

Okamura, Mihoko. 2009. Rodosha haken-ho kaisei mondai [On the revision of the Worker Dispatching Act]. Refarensu 10 (705). 119-139.

Satō, Hiroki. 24 August 2006. Kakusa to tayōka soshite atarashii kyaria keisei [Disparity, diversification, and new forms of career development]. Nihon Keidanren Times No. 2826. http://www.keidanren.or.jp/japanese/journal/times/2006/0824/ 04.html (accessed 21 April 2010).

Satō, Hiroki. 2008. Jinzai haken to iu hatarakikata no "ima" o yomitoku [Understanding the "present" of human resource dispatching as a way of work]. Vistas Adecco 5. 4-7.

SSG (Shakai Seisaku Gakkai) (ed.). 1999. Hiyatoi rodosha, homuresu to gendai Nippon [Day laborers and homeless in contemporary Japan]. Tokyo: Ochanomizu Shobō.

Suzuki, Akira. 2008. Community unions in Japan: Similarities and differences of region-based labour movements between Japan and other industrialized countries. Economic and Industrial Democracy 29. 492-520.

Takanashi, Akira. 1987. Shokai: Rodosha haken-ho [Worker Dispatching Act: Detailed exposition]. Tokyo: Nihon rōdō kyōkai.

Tōkairin, Satoshi. 2008. Hinkon no genba [Theaters of poverty]. Tokyo: Mainichi Shinbunsha.

THJI (Toshikoshi Haken Mura Jikkō Iinkai) (ed.). 2009. Haken Mura: Kuni o ugokashita 6-kakan [Temp Village: 6 days of prodding the state towards change]. Tokyo: Mainichi Shinbunsha.

Tsukada, Tsutomu. 2005. Dakara San'ya wa yamerarene: Boku ga hiyatoi rodosha datta 180 nichi [San'ya is hard to leave: My 180 days as a day laborer]. Tokyo: Gentōsha.

Utsunomiya, Kenji \& Makoto Yuasa (eds.). 2009. Haken Mura: Nani ga towarete iru no $k a$ [Temp Village: Issues at stake]. Tokyo: Iwanami Shoten. 
Yuasa, Makoto. 2009 [2005]. Anata ni mo dekiru! Honto ni komatta hito no tame no seikatsu hogo shinsei manyuaru [You too can! Welfare assistance application manual for those truly in need]. Tokyo: Dobunkan.

Wakita, Shigeru. 2008. Rodosha no kenri, danketsu kaitai to "Nihonteki" rodosha haken ["Japanese" labor dispatching and the dissolution of workers' rights and solidarity]. Tsubute 60. 119-129. 